\title{
EFFECT OF BETAINE SUPPLEMENTATION TO METHIONINE ADEQUATE DIET ON GROWTH PERFORMANCE, CARCASS CHARACTERISTICS, SOME BLOOD PARAMETERS AND ECONOMIC EFFICIENCY OF BROILERS \\ El-Shinnawy, A. M. \\ Regional Center for Food and Feed, Agric. Res. Center, Cairo-Egypt.
}

\begin{abstract}
The objective of this study was to evaluate the influence of supplementing betaine to broiler diets containing adequate concentration of methionine on growth performance, carcass traits and some blood parameters, as well as economic efficiency. Two hundred and sixty day-old Ross broiler chicks were allotted into five equal treatments of four equal replications. Five experimental isonitrogenous and isocaloric diets with graded levels of betaine $(0.0,1.0,1.5,2.0$ and $2.5 \mathrm{~g} / \mathrm{kg}$ diet) were formulated and fed to chicks from 1 to 39 days of age.

During the entire experimental period, dietary betaine supplementation had positive effects on mortality rate, economic efficiency and growth performance (weight gain, feed conversion ratio, protein efficiency ratio, efficiency of energy utilization and performance index) of broiler chicks but feed intake was not affected. Broilers fed the betaine-supplemented diets exhibited significantly higher percentages of carcass yield, total edible parts, breast yield and breast meat while those of heart and abdominal fat were decreased but relative weights of giblets, liver and gizzard were not affected compared with their control counterparts. Feeding the betainesupplemented diets also produced a positive effect on liver and breast meat composition (increased crude protein and decreased ether extract contents of both) compared with the control group. Dietary supplementation with betaine led to significant increases in serum concentrations of total protein, globulin, triglycerides and total cholesterol but levels of glucose and albumin were not affected. Taking the economic aspect into account, it is concluded that supplemental betaine can be used to improve growth performance and carcass quality of broilers fed methionine adequate diets. Based on the present results, a supplemental dietary betaine level of $1.0 \mathrm{~g} / \mathrm{kg}$ diet is suggested to be enough to exert such beneficial effects.
\end{abstract}

\section{INTRODUCTION}

Feed additives are important materials that can improve the efficiency of feed utilization and animal performance (Abdou, 2011). Recently, betaine has been used as a dietary feed supplement in animal nutrition. Betaine is present in sugar beets, seafoods and other plants and animals (Wang et al., 2004). Nowadays, betaine is also available in several purified forms (anhydrous, monophosphate and hydrochloride betaine).Betaine has two metabolic roles: it is a methyl group donor and it is an osmolyte that assists in cellular water homeostasis (Petronini et al., 1992). Betaine, choline and methionine can serve as a source of methyl (CH3) groups (Kettunen et al., 2001). Some studies (Virtanen and Rossi, 1995) suggested that the response to betaine was greater than that obtained from the addition of methionine, but other studies have failed to demonstrate that the methionine content of the diet could be reduced by supplementation with betaine 
(Rostagno and Pack, 1996; McDevitt et al., 2000). However, several studies pointed out that addition of betaine may improve breast meat yield (Schutte et al., 1997; McDevitt et al., 2000). Betaine is indirectly involved in the synthesis of carnitine which is required for transporting long-chain fatty acids across the inner mitochondrial membrane for oxidation (McDevitt et al., 2000) and may result in a leaner carcass. Many consumers prefer the lean products. Therefore, the present study was designed to evaluate the response of broiler chicks fed methionine adequate diets to supplemental betaine.

\section{MATERIALS AND METHODS}

Chicks and experimental design:

The present work was conducted in an environmentally controlled house in the Regional Center for Food and Feed (RCFF), Agricultural Research Center, Giza, Egypt. Two hundred and sixty day-old Ross broiler chicks, obtained from a commercial hatchery, were divided into five dietary treatments with four equal replications each. Birds were kept in battery cages and had free access to feed and water, and managed similarly. Birds were vaccinated against New Castle, Avian influenza and Gamboro diseases. After such medical treatments, a dose of vitamins $\left(\mathrm{AD}_{3} \mathrm{E}\right)$ was offered in the drinking water for three successive days.

\section{Experimental diets:}

The experiment was conducted for three phases: starter (14 days) grower (14 days) and finisher (11 days). All birds were fed corn soybean meal-based diets that were formulated to meet all nutrients required by broilers as recommended by NRC (1994). The crude protein (CP) and metabolizable energy (ME) contents of the basal diets destined for the starter, grower and finisher phases were $23.12 \% \mathrm{CP} ; 3070 \mathrm{kcal} \mathrm{ME}, 21.47 \%$ $\mathrm{CP} ; 3146 \mathrm{kcal} \mathrm{ME}$ and $20.15 \% \mathrm{CP}, 3198 \mathrm{kcal} \mathrm{ME} / \mathrm{kg}$, respectively. Betaine (as anhydrous product) was added to each basal diet at levels of 0.0, 1.0, $1.5,2.0$ and $2.5 \mathrm{~g} / \mathrm{kg}$, thus five diets were formulated and used. Composition and calculated analysis of the basal diets are presented in Table 1. The tested feed additive (betaine) was purchased from a local commercial market. Furthermore, the ME values of these diets were also calculated according to NRC ( 1994).

Composition of vitamin and minerals premix. Each $3 \mathrm{~kg}$ of vitamin and mineral mixture contains: $12,000,000 \mathrm{IU}$ vitamin $\mathrm{A} ; 2,000,000 \mathrm{IU}$; vit. $\mathrm{D}_{3} ; 10 \mathrm{~g}$ vit. E; $1.0 \mathrm{~g}$ vit. $K ; 1.0 \mathrm{~g}$ vit. $B_{1} ; 5.0 \mathrm{~g}$ vit. $B_{2}, 1500 \mathrm{mg}$ vit. $B 6,10 \mathrm{mg}$ vit. $B_{12} ; 10$ $\mathrm{g}$ pantothenic acid; $20 \mathrm{~g}$ nicotinic acid; $1.0 \mathrm{~g}$ folic acid; $50 \mathrm{mg}$ biotin; $500 \mathrm{~g}$ choline chloride; $4.0 \mathrm{~g}$ copper; $300 \mathrm{mg}$ iodine; $30 \mathrm{~g}$ iron; $60 \mathrm{~g}$ manganese; 50 $\mathrm{g}$ zinc and $100 \mathrm{mg}$ selenium.

\section{Performance criteria:}

Live body weights and weight gains $(\mathrm{g})$ of chicks were recorded at 14,28 and 39 days of age and for the entire experimental period (1-39) days of age, while feed consumption $(\mathrm{g})$ and feed conversion ratio ( $\mathrm{g}$ feed/g gain) were calculated weekly. 
Table (1): Composition and calculated analysis of the basal diets

\begin{tabular}{|c|c|c|c|}
\hline Ingredients & $\begin{array}{c}\text { Starter } \\
(1-14 \text { days of age }) \\
\%\end{array}$ & $\begin{array}{c}\text { Grower } \\
\text { (14-28 days of } \\
\text { age) } \\
\%\end{array}$ & \begin{tabular}{|c} 
Finisher \\
(28-39 days of \\
age)
\end{tabular} \\
\hline Yellow corn & 55.710 & 59.600 & 61.800 \\
\hline Soybean meal (46 CP\%) & 30.000 & 25.500 & 24.000 \\
\hline Corn gluten meal & 7.800 & 7.900 & 7.000 \\
\hline Vegetable oil & 2.430 & 2.915 & 3.545 \\
\hline Di-calcium phosphate & 1.740 & 1.960 & 1.760 \\
\hline Limestone & 0.820 & 0.560 & 0.560 \\
\hline DL- methionine & 0.210 & 0.200 & 0.140 \\
\hline L- lysine-HCl & 0.420 & 0.490 & 0.320 \\
\hline Common-salt ( $\mathrm{NaCl})$ & 0.400 & 0.400 & 0.400 \\
\hline Vitamin and Mineral premix & 0.400 & 0.400 & 0.400 \\
\hline Choline chloride & 0.070 & 0.075 & 0.075 \\
\hline Total & 100.000 & 100.000 & 100.000 \\
\hline \multicolumn{4}{|c|}{ Calculated analysis } \\
\hline Dry matter, \% & 87.97 & 88.11 & 88.23 \\
\hline Crude protein, \% & 23.12 & 21.47 & 20.15 \\
\hline Crude fat, $\%$ & 4.78 & 4.53 & 4.33 \\
\hline Crude fiber, \% & 3.65 & 3.88 & 3.61 \\
\hline Ash, \% & 5.85 & 5.75 & 5.98 \\
\hline $\mathrm{ME}(\mathrm{Kcal} / \mathrm{kg})$ & 3065.9 & 3145.55 & 3197.73 \\
\hline Calcium, \% & 0.96 & 0.90 & 0.85 \\
\hline Avail. Phosphorus, \% & 0.45 & 0.48 & 0.40 \\
\hline Mehionine, \% & 0.61 & 0.584 & 0.500 \\
\hline Mehionine + cystine, \% & 0.98 & 0.950 & 0.850 \\
\hline Lysine, $\%$ & 1.36 & 1.300 & 1.130 \\
\hline
\end{tabular}

\section{Efficiency of protein and energy utilization:}

Protein efficiency ratio (PER) and efficiency of energy utilization (EEU) values were calculated during all the studied growth periods according to the equations of Persia et al. (2003) and Ali (1999) as follows: PER = (Body weight gain (g)/crude protein consumed $(\mathrm{g})$. EEU = (ME consumed kcal / g body weight gain).

Performance index (PI):

Performance index (PI) was also calculated during the studied growth periods according to the equation of North (1984) and Ali (1999) as follows: $\mathrm{PI}=$ (Live body weight $(\mathrm{kg}) /$ feed conversion ratio) $\times 100$.

\section{Carcass traits:}

At the end of the experiment (39 days of age), six birds from each treatment, with average body weight nearly similar to the mean body weight of their respective treatment, were chosen, fasted for about 10 hours. Birds were individually weighed before and after slaughtering and complete bleeding. Feathers were removed with hand to insure complete defeathering. 
Head, neck, wings and shanks were cut, and separately weighed. Thereafter, carcasses were cut at the posterior end of sternum and abdominal fat was removed and weighed. Weights of eviscerated carcass and its components (i.e. giblets, breast yield, total edible parts and abdominal fat) were expressed as absolute or percent of LBW at slaughter. The breast meat of each carcass was dissected and weighed. Samples were taken from liver and breast meat and stored at $-20^{\circ} \mathrm{C}$ for subsequent analyses of crude protein (CP) and ether extract (EE) contents. The weights of the liver without gallbladder, gizzard without feed contents and heart without vessels and blood, were recorded. Dressing percentage (i.e. total edible parts) was calculated as carcass weight plus total giblets weight relative to pre-slaughtered weight of the bird, whereas breast meat yield was calculated as present of the eviscerated carcass weight.

Blood parameters:

Individual blood samples $(3 \mathrm{ml})$ were taken during slaughtering from the individual birds. The blood samples were immediately centrifuged at 3000 $\mathrm{rpm}$ for 15 minutes and the serum was stored at $-20^{\circ} \mathrm{C}$ in sealed container till analysis. Serum concentrations of total protein and albumin were determined according to Doumas et al. (1981) and Doumas et al. (1971), respectively. Globulin concentration was calculated as the difference between serum total protein and albumin. Total cholesterol was determined according to Watson (1960). Plasma triglycerides were determined according to the method of Fossati and and Prencipe (1982). Plasma glucose was determined according to the procedure of Coles (1986).

Economic efficiency:

For economic efficiency (EE) determination, all managerial factors affecting meat production of broilers were considered constants, and the amounts of feed consumption and weight gains per treatment were calculated. Prices of experimental diets and the tested feed additive (betaine) were also calculated according to the prevailing prices of local market at the time of the experiment. Economic efficiency was calculated as net revenue/total cost per bird.

\section{Statistical analysis:}

Data from all response variables were subjected to one-way analysis of variance using General Liner Model (GLM) of SAS/STAT software (SAS Institute, 2004). Significant difference among treatment means of different variables were separated using Duncan's multiple range procedure (Duncan, $1955)$ at $5 \%$ probability.

\section{RESULTS AND DISCUSSION}

\section{Growth performance:}

The effect of feeding diets supplemented with different levels of betaine on live body weight, weight gain, feed intake and feed conversion during starter (1-14), grower (14-28) and finisher (28-39 days of age) phases of growth of broilers are presented in Table 2. The results obtained indicated that feeding betaine-supplemented diets positively affected 39 days old live body weight (LBW) of broiler chicks compared with their control group. The 
highest LBW was achieved by chicks fed the diet supplemented with $1.0 \mathrm{~g} / \mathrm{kg}$ betaine, followed by those fed the diets supplemented with $2.0,2.5,1.5$ and $0.0 \mathrm{~g} / \mathrm{kg}$ betaine, in a descending order, respectively. The same trend of response was observed in body weight gain (BWG) of chicks fed the betainesupplemented diets during the whole experimental period compared with their control counterparts.

As indicated in Table 2, the effects of dietary supplementation with betaine on feed intake $(\mathrm{FI})$ of broilers during the different phases of growth were inconclusive. Dietary treatments did not affect F1 of broilers during the starter and finisher phases of growth but had a negative effect on FI of birds during the grower and the entire experimental periods compared with those of the control group. Such slight differences among the different experimental groups of broiler chicks in FI, observed herein, seemed erratic and perhaps are not related to the effect of dietary treatments. However, dietary supplementation with different levels of betaine led to superior means of feed conversion ratio during the three phases of growth and the whole experimental period to those attained by the control group. There were no significant differences in total mortality rates, reported in the present study (Table 2), among the different experimental groups of broilers in response to dietary supplementation with graded levels of betaine.

It is evident that supplementation with betaine to broiler diets produced a positive effect on body weight gain and feed conversion ratio when compared with those of the control group. On the other hand, EsteveGarica and Mack (2000) stated that the effect of supplemental betaine on body weight and feed to gain of broilers was relatively small and not significant. Moreover, betaine significantly improved body weight and feed conversion of Matrouh chickens at a level of $1.0 \mathrm{~g} / \mathrm{kg}$ diet (Ezzat et al., 2011).

The results of the present study indicated also that feed intake of broiler was not affected by supplementation levels of betaine in diets. This is in agreement with those obtained by Jahanian and Rahmani (2008), who found that dietary betaine had no effect on feed intake of broilers. It was interesting to note that all birds consuming betaine-supplemented diets had somewhat lower FI values as compared to birds fed the control diet. The reason for reduced feed intake, observed herein, caused by betaine is not known. The results, however, showed that the reduction of feed intake by betaine was not coincided with a negative effect on growth of broiler chickens and therefore led to an improved feed efficiency. However, Honarbakhsh et al. (2007) and Dorra et al. (2012) indicated that betaine supplementation increased feed intake, which is in contrast to the present results.

In accordance with the present results, Tolba et al. (2007) showed that dietary supplemental betaine improved feed conversion and live body weight as compared to the respective control. Honarbakhsh et al (2007) stated that betaine supplementation increased body weight and improved 
feed conversion ratio of broiler chicks in grower and finisher periods. Furthermore, betaine is an osmolyte that could improve intestinal structure and function to increase growth performance (Honarbakhsh et al., 2007; Zulkifli et al., 2004). Generally, a positive effect of betaine was indicated on performance of broiler (Hamidi et al., 2010) and ducks (Wang et al., 2004). The observed values of mortality rate in this study are lower than those obtained previously by Tollba et al. (2004), who found that mortality rate was $5 \%$ for broiler chicks reared in normal conditions $\left(24^{\circ} \mathrm{C}\right)$.

Protein efficiency ratio (PER), efficiency of energy utilization (EEU) and performance index $(\mathrm{PI})$ :

The effects of feeding broilers diets supplemented with different levels of betaine on PER and EEU and PI of broilers throughout the entire experimental period are summarized in Table 3.

\section{Efficiency of protein and energy utilization:}

As illustrated in Table 3, PER of broiler chicks fed the betainesupplemented diets for the three phases of growth, investigated herein, were significantly better than those of the control birds. During the entire experimental period, the best PER was achieved by broilers fed the diet supplemented with $1.0 \mathrm{~g} / \mathrm{kg}$ betaine, followed by those of birds fed the diets fortified with 2.5, 2.0, 1.5 and $0.0 \mathrm{~g} / \mathrm{kg}$ betaine in a descending order, respectively. Similarly, EEU of broiler chicks was positively affected by dietary supplementation with graded levels of betaine during all phases of growth compared with those of their control counterparts (Table 3). In addition, PI values of broiler chicks fed the betaine-supplemented diets were superior to those of the control birds, in a similar trend of response (Table 3).

\section{Carcass characteristics:}

Carcass characteristics of broiler chickens as affected by dietary treatments are given in Table 4. The results revealed that birds fed on rations supplemented with betaine showed significantly $(P<0.05)$ higher percentages of carcass yield, total edible parts and breast yield than those of the controls. On the other hand, the percentages of liver, gizzard and giblets were not affected by dietary treatments.

The results obtained are in agreement with those obtained by ElGanzory et al. (2004), who found no significant variations in broiler liver percentage in response to supplemental betaine. In this respect, Wang et al. (2004) suggested that betaine is more effective in improving carcass quality. Attia et al. (2005) indicated that betaine supplementation significantly improved the percentage of carcass yield in chicks. Esteve-Garcia and Mack (2000) suggested that betaine supplementation may improve carcass yield. On the other hand, Deng and Wang (1997) indicated that addition of betaine did not affect dressing percentage of broiler chicks. In addition, Esteve-Garcia and Mack (2000) reported that the effects of betaine on breast yield were relatively small and non-significant. All of these studies indicated that growth of different tissues in broiler chickens responded to betaine supplementation differently. 
Table (2): Effect of feeding diets supplemented with different levels of betaine on body weight (BW), weight gain (WG), feed intake (FI), feed: gain ratio ( $F: G)$ and mortality rate of broiler chicks

\begin{tabular}{|c|c|c|c|c|c|}
\hline Items & Tr. 1 (control) & Tr. 2 & Tr. 3 & Tr. 4 & Tr. 5 \\
\hline Initial weight (g) & 42.1 & 42.3 & 42.5 & 42.1 & 42.0 \\
\hline \multicolumn{6}{|c|}{ BW (g) at: } \\
\hline 14 day & $314.4^{c}$ & $332.3^{\mathrm{a}}$ & $322.2^{c}$ & $325.4^{\mathrm{ab}}$ & $322.3^{\mathrm{D}}$ \\
\hline 28 day & $1121.5^{\mathrm{C}}$ & $1154.5^{b}$ & $1136.5^{\mathrm{C}}$ & $1170.8^{\mathrm{a}}$ & $1141.9^{b}$ \\
\hline 39 day & $1853.9^{\mathrm{d}}$ & $1959.2^{\mathrm{a}}$ & $1898.5^{\mathrm{C}}$ & $1931.5^{D}$ & $1929.4^{D}$ \\
\hline \multicolumn{6}{|c|}{ WG (g) at: } \\
\hline 1-14 day & $272.3^{c}$ & $290.0^{\mathrm{a}}$ & $279.7^{b}$ & $283.3^{\text {ab }}$ & $280.3^{b}$ \\
\hline 14-28 day & $807.1^{\mathrm{C}}$ & $822.2^{b}$ & $814.3^{b}$ & $845.4^{\mathrm{a}}$ & $819.6^{b}$ \\
\hline 28-39 day & $732.4^{\mathrm{d}}$ & $804.7^{\mathrm{a}}$ & $762.0^{C}$ & $760.7^{\mathrm{C}}$ & $787.5^{b}$ \\
\hline 1-39 day & $1811.8^{\mathrm{d}}$ & $1916.9^{a}$ & $1856.0^{C}$ & $1889.4^{D}$ & $1887.4^{D}$ \\
\hline \multicolumn{6}{|c|}{ FI (g) at: } \\
\hline 1-14 day & 361.8 & 365.4 & 363.5 & 366.5 & 362.7 \\
\hline 14-28 day & 1287.9 & 1259.0 & 1273.6 & 1270.8 & 1257.8 \\
\hline 28-39 day & 1356.8 & 1351.7 & 1356.2 & 1357.8 & 1363.1 \\
\hline 1-39 day & 3006.5 & 2976.1 & 2993.3 & 2995.1 & 2983.6 \\
\hline \multicolumn{6}{|c|}{$(F: G)$ at: } \\
\hline 1-14 day & $1.33^{\mathrm{a}}$ & $1.23^{\mathrm{C}}$ & $1.25^{\mathrm{C}}$ & $1.29^{\circ}$ & $1.29^{\mathrm{D}}$ \\
\hline 14-28 day & $1.60^{\mathrm{a}}$ & $1.53^{\mathrm{C}}$ & $1.52^{\mathrm{C}}$ & $1.50^{\mathrm{C}}$ & $1.53^{\mathrm{C}}$ \\
\hline 28-39 day & $1.85^{\mathrm{a}}$ & $1.67^{\mathrm{C}}$ & $1.77^{\mathrm{b}}$ & $1.78^{\mathrm{b}}$ & $1.73^{b}$ \\
\hline 10-39 day & $1.66^{\mathrm{a}}$ & $1.55^{\mathrm{C}}$ & $1.61^{\mathrm{D}}$ & $1.59^{D}$ & $1.58^{D}$ \\
\hline Mortality\% (1-39 day) & 3.85 & 1.92 & 1.92 & 0.00 & 1.92 \\
\hline
\end{tabular}

a-d: Means at the same row with different superscripts differ significantly $(P<0.05)$. .

Table (3): Effect of feeding diets supplemented with different levels of betaine on protein efficiency ratio (PER), efficiency of energy utilization (EEU) and performance index (PI) of broiler chicks

\begin{tabular}{|c|c|c|c|c|c|}
\hline Items & $\begin{array}{c}\text { Tr. } 1 \\
\text { (control) }\end{array}$ & Tr. 2 & Tr. 3 & Tr. 4 & Tr. 5 \\
\hline \multicolumn{6}{|c|}{ Protein efficiency ratio (PER) at: } \\
\hline $1-14 d$ & $3.25^{\mathrm{C}}$ & $3.46^{\mathrm{a}}$ & $3.33^{\mathrm{b}}$ & $3.34^{\mathrm{b}}$ & $3.34^{\mathrm{b}}$ \\
\hline $14-28 \mathrm{~d}$ & $2.92^{\mathrm{C}}$ & $3.05^{\mathrm{a}}$ & $2.99^{\mathrm{D}}$ & $3.10^{a}$ & $3.04^{\mathrm{a}}$ \\
\hline $28-39 \mathrm{~d}$ & $2.66^{\mathrm{d}}$ & $2.95^{\mathrm{a}}$ & $2.79^{C}$ & $2.78^{\mathrm{C}}$ & $2.87^{b}$ \\
\hline $1-39 \mathrm{~d}$ & $2.75^{\mathrm{C}}$ & $2.99^{\mathrm{a}}$ & $2.88^{\mathrm{D}}$ & $2.92^{\mathrm{a}}$ & $2.93^{\mathrm{a}}$ \\
\hline \multicolumn{6}{|c|}{ Efficiency of energy utilization (EEU) at: } \\
\hline $1-14 \mathrm{~d}$ & $4.07^{\mathrm{a}}$ & $3.86^{\mathrm{c}}$ & $3.99^{\mathrm{D}}$ & $3.97^{D}$ & $3.97^{0}$ \\
\hline $14-28 d$ & $5.02^{\mathrm{a}}$ & $4.82^{\mathrm{C}}$ & $4.92^{b}$ & $4.73^{\mathrm{d}}$ & $4.83^{\mathrm{C}}$ \\
\hline $28-39 \mathrm{~d}$ & $5.92^{\mathrm{a}}$ & $5.37^{\mathrm{C}}$ & $5.69^{\mathrm{b}}$ & $5.71^{\mathrm{b}}$ & $5.53^{\mathrm{C}}$ \\
\hline $1-39 \mathrm{~d}$ & $5.25^{\mathrm{a}}$ & $4.91^{\mathrm{C}}$ & $5.10^{\mathrm{D}}$ & $5.01^{\mathrm{d}}$ & $4.99^{\mathrm{DC}}$ \\
\hline \multicolumn{6}{|c|}{ Performance index (PI) at: } \\
\hline at $14 \mathrm{~d}$ & $23.64^{c}$ & $27.02^{a}$ & $25.78^{D}$ & $25.23^{0}$ & $24.98^{\circ}$ \\
\hline at $28 \mathrm{~d}$ & $70.09^{\mathrm{d}}$ & $81.88^{\mathrm{ab}}$ & $78.92^{\mathrm{C}}$ & $83.63^{a}$ & $80.42^{b}$ \\
\hline at $39 \mathrm{~d}$ & $111.68^{\mathrm{d}}$ & $126.40^{\mathrm{a}}$ & $117.92^{C}$ & $121.48^{b}$ & $122.11^{\mathrm{b}}$ \\
\hline
\end{tabular}

a-d: Means at the same row with different superscripts differ significantly $(P<0.05)$.. 
Several studies suggested that addition of betaine may improve breast meat yield (Schutte et al., 1997; McDevitt et al., 2000). Betaine is indirectly involved in the biosynthesis of carnitine which is required for transporting long chain fatty acids across the inner mitochondrial membrane for oxidation (De Ridder and Van Dam, 1975) and therefore, may result in a leaner carcass, which is more attractive by many consumers. As shown in Table 4 , percentages of abdominal fat of broilers were significantly $(P<0.05)$ reduced as a result of dietary supplementation of betaine. The decrease of abdominal fat of broilers fed betaine-supplemented diets in the present study may be due to increased hepatic synthesis of carnitine and enhanced activity of the hormone-sensitive lipase in the abdominal fat, as reported by Zhan et al . (2006).

Table (4): Effect of feeding different levels of betaine on carcass traits of 39-day-old broiler chicks

\begin{tabular}{|l|c|c|c|c|c|}
\hline \multicolumn{1}{|c|}{ Items } & Tr. 1 (control) & Tr. 2 & Tr. 3 & Tr. 4 & Tr. 5 \\
\hline Live body weight (g) & 1880 & 1860 & 1873 & 1898 & 1837 \\
\hline Carcass yield (\%) & $72.71^{\mathrm{c}}$ & $73.96^{\mathrm{b}}$ & $73.88^{\mathrm{b}}$ & $74.81^{\mathrm{a}}$ & $74.41^{\mathrm{a}}$ \\
\hline Liver (\%) & 2.15 & 1.96 & 2.04 & 2.05 & 2.01 \\
\hline Gizzard (\%) & 2.02 & 1.93 & 2.06 & 1.81 & 1.98 \\
\hline Heart (\%) & $0.60^{\mathrm{a}}$ & $0.48^{\mathrm{b}}$ & $0.46^{\mathrm{b}}$ & $0.46^{\mathrm{b}}$ & $0.50^{\mathrm{b}}$ \\
\hline Giblets (\%) & 4.77 & 4.37 & 4.56 & 4.32 & 4.49 \\
\hline Total edible parts (\%) & $77.48^{\mathrm{c}}$ & $78.33^{\mathrm{b}}$ & $78.44^{\mathrm{b}}$ & $79.44^{\mathrm{b}}$ & $79.23^{\mathrm{a}}$ \\
\hline Abdominal fat (\%) & $1.72^{\mathrm{a}}$ & $1.54^{\mathrm{b}}$ & $1.51^{\mathrm{b}}$ & $1.36^{\mathrm{c}}$ & $1.59^{\mathrm{b}}$ \\
\hline Breast yield (\%) & $23.05^{\mathrm{c}}$ & $24.73^{\mathrm{b}}$ & $25.09^{\mathrm{b}}$ & $24.60^{\mathrm{b}}$ & $26.49^{\mathrm{a}}$ \\
\hline Deboned breast meat (\%) & $17.02^{\mathrm{d}}$ & $19.89^{\mathrm{C}}$ & $20.82^{\mathrm{b}}$ & $21.08^{\mathrm{b}}$ & $22.05^{\mathrm{a}}$ \\
\hline
\end{tabular}

a-d: Means at the same row with different superscripts differ significantly $(P<0.05)$.

The present results are consistent with the findings of Zhan et al. (2006). The abdominal fat pad of broilers usually represents a waste product and added dietary betaine may decrease the carcass fat of broilers, as reported by some authors (Saunderson and Mackinlay, 1990). Although betaine is involved in lipid metabolism, a reduction in carcass fat in poultry as result of betaine supplementation is not clearly documented and more research is needed to help clarify this issue.

Table (5): Contents (\% DM basis) of crude protein and ether extract in breast meat (BM) and liver of 39-day-old broiler chicks as effected by dietary betaine supplementation

\begin{tabular}{|l|c|c|c|c|c|}
\hline \multicolumn{1}{|c|}{ Items } & Tr. 1 (control) & Tr. 2 & Tr. 3 & Tr. 4 & Tr. 5 \\
\hline Crude protein (\%): & & & & & \\
\hline Breast meat (BM) & $78.96^{\mathrm{b}}$ & $80.27^{\mathrm{ab}}$ & $81.85^{\mathrm{a}}$ & $81.91^{\mathrm{a}}$ & $81.97^{\mathrm{a}}$ \\
\hline Liver & $67.56^{\mathrm{c}}$ & $69.15^{\mathrm{D}}$ & $69.49^{\mathrm{a}}$ & $69.55^{\mathrm{a}}$ & $69.67^{\mathrm{a}}$ \\
\hline Ether extract (\%): & & & & & \\
\hline Breast meat (BM) & $4.43^{\mathrm{a}}$ & $3.65^{\mathrm{b}}$ & $3.45^{\mathrm{b}}$ & $3.51^{\mathrm{b}}$ & $3.55^{\mathrm{b}}$ \\
\hline Liver & $17.40^{\mathrm{a}}$ & $16.11^{\mathrm{b}}$ & $15.95^{\mathrm{b}}$ & $13.90^{\mathrm{c}}$ & $13.55^{\mathrm{c}}$ \\
\hline
\end{tabular}

a-c: Means at the same row with different superscripts differ significantly $(P<0.05)$.

As shown in Table 5, betaine supplementation had a positive effect $(P<0.05)$ on CP and EE contents of breast meat of broiler chicks. Birds fed supplemental betaine at levels of $1.5,2.0$ and $2.5 \mathrm{~g} / \mathrm{kg}$ had significantly 
$(P<0.05)$ higher CP contents in their breast meat than those of the control group. Similarly, CP contents in the liver samples of broilers fed betainesupplemented diets were also significantly $(P<0.05)$ higher than that of broilers fed the control diet (Table 5). The current results are in accordance with those observed by McDevitt et al. (2000), who found that added dietary betaine improved breast meat yield of broiler chicks. Betaine may have a positive effect on partitioning the nutrients in favor of protein synthesis in breast meat. On the other hand, the EE contents of the breast and liver of broilers fed the diets supplemented with betaine were significantly lower $(\mathrm{P}<0.05)$ compared with those of the control birds (Table 5).

In this respect, Sun et al. (2008) indicated that supplementation of betaine at different levels lead to high concentrations of growth hormone and insulin-like growth factor-1 coincided with increased breast meat yield (\%) and its protein content, but reduced abdominal fat and EE content of the breast and liver as compared to those of the control birds. In addition, $\mathrm{Xu}$ and Zhan (1998) showed that betaine supplementation enhanced the synthesis of methylated compounds such as carnitine that is required for the transport of long-chain fatty acids through the inner mitochondrial membrane where fatty acid oxidation takes place and this might be involved in reducing carcass and liver lipid contents.

Blood parameters:

Blood represents an important index of physiological, pathological and nutritional status of the organism. Changes in the constituent compounds of blood when compared to normal values could be used to interpret the metabolic status of an animal and perhaps nutrient adequacy of the feed consumed (Nworgu et al., 2007).

The effect of dietary treatments on serum biochemical parameters of 39-day-old broiler chicks are shown in Table 6. Dietary treatments had no significant effect on serum glucose concentration when compared to that of their control birds. It is worth noting that blood serum levels of glucose, reported in this study, were in the normal range $(180-250 \mathrm{mg} / \mathrm{dl})$ that previously reported by Bounous et al. (2000). However, Zou and Lu (2002) stated that betaine supplementation induced a significant increase in serum glucose in laying hens.

Table (6): Concentrations of some blood serum constituents of broiler chicks as affected by dietary betaine supplementation

\begin{tabular}{|l|c|c|c|c|c|}
\hline \multicolumn{1}{|c|}{ Measurements } & $\begin{array}{c}\text { Tr. 1 } \\
\text { (control) }\end{array}$ & Tr. 2 & Tr. 3 & Tr. 4 & Tr. 5 \\
\hline Total cholesterol (mg/dl) & $114.6^{\mathrm{b}}$ & $119.2^{\mathrm{b}}$ & $138.5^{\mathrm{a}}$ & $133.5^{\mathrm{a}}$ & $136.6^{\mathrm{a}}$ \\
\hline Triglycerides $(\mathrm{mg} / \mathrm{dl})$ & $26.6^{\mathrm{d}}$ & $43.8^{\mathrm{a}}$ & $39.9^{\mathrm{b}}$ & $36.1^{\mathrm{b}}$ & $33.8^{\mathrm{c}}$ \\
\hline Glucose $(\mathrm{mg} / \mathrm{dl})$ & 194.3 & 195.5 & 203.8 & 196.8 & 193.3 \\
\hline Alb $(\mathrm{g} / \mathrm{dl})$ & 1.3 & 1.4 & 1.5 & 1.5 & 1.4 \\
\hline Total protein $(\mathrm{g} / \mathrm{dl})$ & $3.05^{\mathrm{c}}$ & $3.26^{\mathrm{b}}$ & $3.48^{\mathrm{b}}$ & $3.26^{\mathrm{b}}$ & $3.45^{\mathrm{a}}$ \\
\hline Globulin (g/dl) & $1.75^{\mathrm{c}}$ & $1.86^{\mathrm{b}}$ & $1.98^{\mathrm{a}}$ & $1.90^{\mathrm{b}}$ & $2.02^{\mathrm{a}}$ \\
\hline
\end{tabular}

a-d: Means at the same row with different superscripts differ significantly $(P<0.05)$. 
Dietary treatments also had no significant effect on serum albumin content of broilers (Table 6). The levels of serum albumin, reported herein, are in line with those obtained by Rama Rao et al. (2011), who found that albumin concentrations were not affected by supplementation of betaine in the broiler diet. Blood serum concentrations of triglycerides were significantly $(P<0.05)$ increased in response to dietary betaine supplementation compared with that of the control group (Table 6). The obtained levels of serum triglycerides are in a disagreement with the findings of Rama Rao et al. (2011), who found that dietary supplementation of betaine did not significantly affect serum concentration of triglycerides in broiler chicks. However, Zhan et al. (2006) found that betaine addition increased the concentration of free fatty acids in serum of broiler chicks.

As given in Table 6 , broilers fed the 1.5 to $2.5 \mathrm{~g} / \mathrm{kg}$ betainesupplemented diets exhibited significantly higher $(P<0.05)$ levels of serum cholesterol when compared with the control group. Similar results were obtained by Rama Rao et al. (2011), who revealed that betaine supplementation significantly increased the concentration of total cholesterol in serum of broiler chicks. However, Konca et al. (2008), Attia et al. (2005) and Baghaei et al. (2011) indicated that betaine supplementation had no significant effect on blood cholesterol level. Yet, all the measured blood parameters of broiler chicks fell within the normal ranges published in the scientific literature. It was observed that the serum total protein and globulin concentrations showed a significant increase $(P<0.05)$ in betainesupplemented groups than those of the control group (Table 6). These results are in accordance with those obtained by Rama Rao et al. (2011), who revealed that dietary betaine supplementation caused a significant increase in serum total protein of broiler chickens. On the other hand, Attia et al. (2005) reported slight increase in serum level of total protein due to dietary betaine supplementation in slow growing chicks..

It is of interest to note that the observed increase in concentration of serum total proteins of broiler chicks in the present study was associated with increasing the concentration of both albumin and globulin. In conclusion, the present results suggested that addition of betaine to broiler diets had no effect on some blood parameters of broilers.

\section{Economic efficiency:}

Economical evaluation of feeding diets supplemented with graded levels of betaine to broiler chicks from 1 to 39 days of age are presented in Table 7. It is obviously that feeding diets supplemented with betaine numerically decreased production cost kg LBW as compared to that of the control. It is worthy to note that supplementing a low level of betaine $(1.0 \mathrm{~g} / \mathrm{kg}$ feed) to basal diet led to a reduction in feed cost (per bird or per kg LBW) as compared to the higher levels of added betaine.

Average economic efficiency values of different dietary treatments ranged between 0.89 and 1.04 , being the best for broilers fed the lowest level of added betaine $(1.0 \mathrm{~g} / \mathrm{kg})$ to the worst $(0.89)$ for chicks fed the control diet. The relative increases in economic efficiency of broilers due to betaine supplementation ranged between 8.0 and $17.0 \%$. These improvements could 
be attributed to the improved body weight gain and feed conversion, obtained herein, in response to dietary betaine supplementation.

Table (7): Effect of feeding diets supplemented with different levels of betaine on economic efficiency of broiler chicks from 1 to 39 days of age

\begin{tabular}{|c|c|c|c|c|c|}
\hline \multirow[b]{2}{*}{ Items } & \multicolumn{5}{|c|}{ Dietary treatments } \\
\hline & $\begin{array}{c}\text { Tr. } 1 \\
\text { (control) }\end{array}$ & Tr. 2 & Tr. 3 & Tr. 4 & Tr. 5 \\
\hline Fixed Cost (LE) ${ }^{a}$ & 3.50 & 3.50 & 3.50 & 3.50 & 3.50 \\
\hline \multicolumn{6}{|l|}{ Feed intake (g/bird): } \\
\hline Starter diet & 361.8 & 365.4 & 363.5 & 366.5 & 362.7 \\
\hline Grower diet & 1287.9 & 1259.0 & 1273.6 & 1270.8 & 1257.8 \\
\hline Finisher diet & 1356.8 & 1351.7 & 1356.2 & 1357.8 & 1363.1 \\
\hline \multicolumn{6}{|l|}{ Feed cost (LE/bird): } \\
\hline Starter diet & 1.41 & 1.43 & 1.42 & 1.44 & 1.42 \\
\hline Grower diet & 4.83 & 4.73 & 4.62 & 4.79 & 4.75 \\
\hline Finisher diet & 4.95 & 4.72 & 4.97 & 4.98 & 5.01 \\
\hline Feed cost/bird (LE) ${ }^{\mathrm{b}}$ : & 11.19 & 10.88 & 11.01 & 11.21 & 11.18 \\
\hline Total cost/bird(LE) ${ }^{\mathrm{C}}$ : & 14.69 & 14.38 & 14.51 & 14.71 & 14.68 \\
\hline BW $(\mathrm{kg})$ & 1.853 & 1.959 & 1.899 & 1.932 & 1.929 \\
\hline Cost/kg BW (LE): & 7.93 & 7.34 & 7.64 & 7.61 & 7.61 \\
\hline Total income (LE) & 27.80 & 29.39 & 28.49 & 28.98 & 28.94 \\
\hline Net revenue (LE)e: & 13.11 & 15.01 & 13.98 & 14.27 & 14.26 \\
\hline Economic efficiency ${ }^{\top}$ : & 0.89 & 1.04 & 0.96 & 0.97 & 0.97 \\
\hline $\begin{array}{l}\text { Relative economic } \\
\text { efficiency }{ }^{\mathrm{h}} \%\end{array}$ & 100 & 117 & 108 & 109 & 109 \\
\hline
\end{tabular}

Where: $c=(a+b), e=(d-c)$ and $f=(e / c) . h=$ economic efficiency of treatment relative to that of control.

Sale price/kg LBW $=15$ LE.

\section{REFERENCES}

Abdou, M.M. (2011). Effect of some medicinal plants in the ration on productive performance of lactating animals, Ph. D. Thesis, Fac. Agric, Ain Shams Univ.

Ali, Mervat A. (1999). Effect of probiotics addition to broiler rations on performance and some blood constituents. Egypt Poult. Sci. J., 19: 161-177.

Attia, Y.A.; R.A. Hassan; M.H. Shehatta and S.B. Abd-EL-Hady (2005) Growth, carcass quality and serum constituents of slow growing chicks as affected by betaine addition to diets containing2.different levels of methionine . Int. J. Poultry . Sci., $4: 856-865$.

Baghaei, M ; M. Eslami; M. Chaji M. Mamoue and M. Bojarpour (2011). Effect of different levels of DI-Methionine replaced with Betafin on some of blood parameters on broiler chickens. J. Anim. Vet. Adv., 10 (6): 777-779. 
Bounous, D. I.; R. D. Wyatt; P. S. Gibbs; J. V. Kilburn and C.F. Quist (2000). Normal hematologic and serum biochemical reference intervals for juvenile wild turkeys. J. Wildl. Dis., 36(2): 293-296.

Coles, E. H. (1986). Veterinary Clinical Pathology, $4^{\text {th }}$ Ed, published by W.B. Sounders Company, Philadelphia, London Tornado.

Deng, Y.L. and Y.B. Wang (1997). Effect of betaine supplementation to diet on performance and carcass quality of broilers. J. South China Agri. Univ., 18(Suppl.): 30-34.

De Ridder, J.J.M. and K. Van Dam (1975). Control of oxidation by rat liver mitochondria. Biochimica et Biophysica Acta Bioenergetics, 408:112-122.

Dorra, Tork.; Somaya E. Ibrahim and Sh. M. Zayed (2012). Effect of dietary betaine supplementation on growth performance and carcass traits of growing turkey. J. Anim. Poultry Prod., Mansoura Univ., 3(7): 365377.

Doumas, B. T.; D.D. Bayse; R.J. Carter; T. Peter and R. Schaffer (1981). A candidate reference method for determination of total protein in serum. 1. Development and validation. Clin. Chem., 27 (10): 16421650.

Doumas B.T.; W.A. Watson and H.G. Biggs (1971). Albumin standards and the measurement of serum albumin with bromocresol green Clin. Chim. Acta, 31:400-403.

Duncan, D. B. (1955). Multiple range and multiple F-tests. Biometrics 11: 142.

El-Ganzory, E.H.; R.A. Hassan and K.E. Moustafa (2004). Effect of betaine and/or sodium sulfate supplementation as a substitute for methionine in chick diets. Egypt. Poult. Sci., 24 (4): 823-843.

Esteve- Garcia, E. and S. Mack (2000). The effect of DL- methionine and betaine on growth performance and carcass characteristics in broilers. Animal Feed Science and Technology, 87; 85-93.

Ezzat, W.; M.S. Shoeib; S.M. Mousa; A.M. Bealish and Z.A. Ibrahiem (2011). Impact of betaine, vitamin $C$ and folic acid supplementations to the diet on productive and reproductive performance of Matrouh poultry strain under Egyptian summer condition. Egypt. Poult. Sci., 31 (2): 521-537.

Firman, K.E.; J.B. Li and J.C. Remus. (1999). Relationship between cysteine and betaine in low methionine diets. Poultry Sci., 78 (Suppl .1):135.

Fossati, P and L. Prencipe (1982). Serum triglycerides determined colorimetrically with an enzyme that produces hydrogen peroxide. Clin. Chem., 28(10): 2077-2080.

Hamidi, H.; R. Jahanian and J. Pourreza (2010). Effect of dietary betaine on performance, immunocompetence and gut contents osmolarity of broilers challenged with a mixed coccidial infection. Asian J. Anim. Vet. Adv, 5 (3): 193-201.

Honarbakhsh, S.; M. Zaghari and M. Shivazad (2007). Can exogenous betaine be an effective osmolyte in broiler chicks under water salinity stress? Asian-Aust. J. Anim. Sci., 20 (11): 1729-1737. 
Jahanian, R. and H.R. Rahmani (2008). The effect of dietary fat level on the response of broiler chicks to betaine and choline supplements. J. Bio. Sci., 8(2): 362-367.

Kettunen, H.; K. Tiihonen; S. Peuranen; M. T. Saarinen and J. C. Remus (2001). Dietary betaine accumulates in liver and intestinal tissues and stabilizes the intestinal epithelial structure in healthy and coccidiainfected broiler chicks. Comp. Biochem. Physiol.. A., 130(4): 130: 759-769.

Konca, Y., F. Kirkpinar; S. Mert and E. Yayalak (2008). Effects of betaine on performance, carcass, bone and blood characteristics of broiler during natural summer temperatures. J. Anim. Vet. Adv., 7 :(8): 930937.

McDevitt, R.M.; S. Mark and I.R. Wallis (2000). Can betaine partially replace or enhance the effect of methionine by improving broiler growth and carcase characteristic? Br. Poult. Sci., 41: 473-480.

NRC, National Research Council (1994). Nutrient Requirement of Poultry. $9^{\text {th }}$ rev. ed., National Academy Press, Washington, DC.

North, M.O. (1984). Commercial Chicken Production Manual. $3^{\text {rd }}$ Ed. AVI., Publishing Company. I.N.C. Westport Connecticut, USA.

Nworgu; F.C.; S.A. Ogungbenro and K.S. Solesi (2007). Performance and some blood chemistry indices of broiler italic chicken served fluted pumpkin (Telfaria occidentals) leaves extract supplement. American Eurasian J. Agric . Environ. Sci., 2 (1): 90-98.

Persia, M.E.; C.M. Persons; M. Schang and J. Azcona (2003). Nutritional evaluation of dried tomato seeds. Poultry Science, 82 (1):141-146.

Petronini, P.G.; E.M. De Angelis; P.Borghetti A.F. Borghetti and K.P. Wheeler (1992). Modulation by betaine of cellular responses to osmotic stress. Biochem. J., 282: 69-73.

Rama Rao, S.V.; M.V.L.N. Raju; A.K. Panda; P. Saharia and G.S. Suder (2011). Effect of supplementing betaine on performance, carcass traits and immune responses in broiler chicken fed diets containing different concentrations of methionine. Asian-Aust. J. Anim. Sci., 24(5): 662-669.

Rostagno, H.S. and M. Pack (1996). Can betaine replace supplemental DLmethionine in broiler diets? J. Appl. Poult Res., 5: 150-154.

SAS Institute (2004). SAS /STAT User's Guide. Release 9.1. SAS inst. Inc., Cary NC., USA.

Saunderson, C.L. and J. Makinlay (1990). Changes in body-weight, composition and hepatic enzyme activities in response to dietary methionine, betaine and choline levels in growing chicks. Br. J. Nutr., 63: 339-349.

Schutte, J.B.; J. de Jong; W. Smink and M. Pack (1997). Replacement value of betaine for Dl-methionine in male broiler chicks. Poult. Sci., 76: 321-325. 
Sun, H.; W.R. Yang; Z.B. Yang; Y. Wang ; S.Z. Jiang and G.G. Zhang (2008). Effects of betaine supplementation to methionine deficient diet on growth performance and carcass characteristics of broilers. American Journal of Animal and Veterinary Sciences, 3(3): 78-84.

Tollba, A.A.H.; M.M. Sabry and S.M.M. Abuzead (2004). Effect of microbial probiotics on performance of broiler chicks under normal or heat stress conditions: 1- Lactobacillus or Pediococcus. Egypt. Poultry Sci., 24(2): 351-367.

Tolba, A.A.H.; S.A.M Shabaan and A.Z. Wagdy (2007). Improvement of Fayoumi laying hens performance under hot climate conditions: 2. Betaine, folic acid and choline. Egypt. Poult. Sci., 27(1): 21-35.

Virtanen, E. and L. Rossi (1995). Effects of betaine on methionine requirement of broilers under various environmental conditions. In :Proceedings of the Australian Poultry Science Symposium, University of Sydney, Australia.

Waldroup, P.W.; M.A. Motl; F. Yan and C.A. Fritts (2006). Effect of betaine and choline on response to methionine supplementation to broiler diets formulated to industry standards. J. Appl. Poult. Res., 15: 58-71.

Wang, Y.Z. (2000). Effect of betaine on growth performance and carcass traits of meat ducks. J. Zhejing Univ. Ag. Life Sci., 26:347-352.

Wang, Y.Z.; Z.R. Xu and J. Feng (2004). The effect betaine and DLmethionine on growth performance and carcass characteristics in meat ducks. Anim. Feed Sci. Thechnol., 116(1/2): 151-159.

Watson, D. (1960). A simple method for the determination of serum cholesterol. Clin. Chim. Acta, 5(5): 637-643.

Xu, Z.R. and X.A. Zhan (1998). Effect of betaine on methionine and adipose metabolism in broiler chickens. Acta Vet. Zootech. Sinica, 29:212219.

Zhan, X.A.; J.X. Li; Z.R. Xu and R.Q. Zhao (2006). Effects of methionine and betaine supplementation on growth performance, carcase composition and adipose metabolism of lipids in male broilers. British Poult. Sci., 47:576-580.

Zou, X.T and J.J. Lu (2002). Effects of betaine on the regulation of the lipid metabolism in laying hen. Agric. Sci., China, 5:1043-1049.

Zulkifli, I; S.A. Mysahra and L.Z. Jin (2004). Dietary supplementation of betaine and reponse to high temperature stress in male broiler chickens. Asian-Aust. J. Anim. Sci., 17:244-249. 


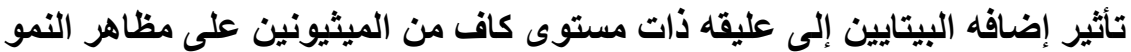

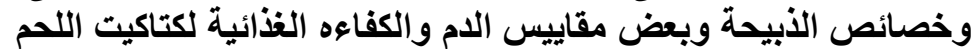
أحمد محمد الثناوى الإيجة المركز الإقليمي للأغذية والأعلاف ـ مركز البحوث الزراعيه

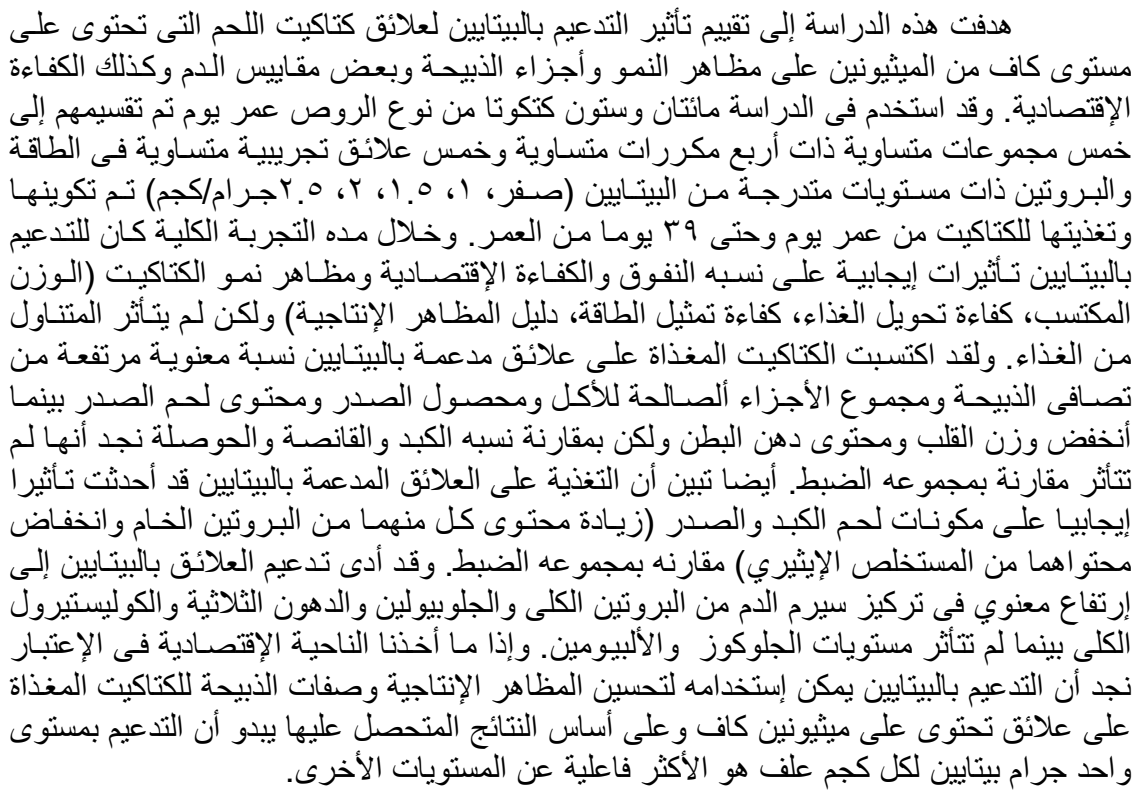

